\title{
PENGARUH KEPUASAN KERJA, FASILITAS KERJA DAN STRES KERJA TERHADAP KINERJA PERSONIL PLETON I YONKAV 6/NK KODAM I BUKIT BARISAN
}

\author{
Yudi Prasetio \\ Universitas Islam Sumatera Utara \\ yudi.prasetyo@gmail.com
}

\begin{abstract}
The term of this study is: Does the job satisfaction, work facility and work stress affect on employee performance at Pleton I YONKAV 6/NK KODAM I BUKIT BARISAN. The aim of the study is to determine the effect of job satisfaction, work facility and work stress of employees performance at Pleton I YONKAV 6/NK KODAM I BUKIT BARISAN.The sample of this study were 50 employees at Pleton I YONKAV 6/NK KODAM I BUKIT BARISAN. The technique of the data analysis in this research is Multiple Linier Regression Analysis. The results of this study show that job satisfaction has a positive and significant influence on Employee Performance; Work Facility has a positive and significant influence on Employee Performance; Work stress has a negative and significant influence on Employee Performance at Pleton I YONKAV 6/NK KODAM I BUKIT BARISAN, finally job satisfaction, work facility and work stress simultaneously have a significant effect on Employee Performance at Pleton I YONKAV 6/NK KODAM I BUKIT BARISAN.
\end{abstract}

Keywords : Job Satisfaction, Work Facility, Work Stress; Employee Performance

ABTSRAK : Rumusan masalah dalam penelitian ini adalah: Apakah kepuasan kerja, fasilitas kerja dan stress kerja berpengaruh terhadap kinerja personil pada Pleton I YONKAV 6/NK KODAM I BUKIT BARISAN. Penelitian ini bertujuan untuk mengetahui pengaruh kepuasan kerja, fasilitas kerja dan stress kerja terhadap kinerja personil pada Pleton I YONKAV 6/NK KODAM I BUKIT BARISAN. Sampel dalam penelitian ini adalah seluruh personil di Pleton I YONKAV 6/NK KODAM I BUKIT BARISAN. yang berjumlah 50 orang. Teknik analisis data dalam penelitian ini adalah Analisis Regresi Linier Berganda. Hasil penelitian ini menunjukkan bahwa kepuasan kerja berpengaruh positif dan signifikan terhadap kinerja personil, selanjutnya fasilitas kerja berpengaruh positif dan signifikan terhadap kinerja personil dan stress kerja berpengaruh negative dan siginifikan terhadap kinerja personil pada Pleton I YONKAV 6/NK KODAM I BUKIT BARISAN, dan terkhir kepuasan kerja, fasilitas kerja dan stres kerja berpengaruh secara simultan terhadap kinerja personil pada Pleton I YONKAV 6/NK KODAM I BUKIT BARISAN.

Kata Kunci : Kepuasan Kerja, Fasilitas Kerja, Stres Kerja dan Kinerja Personil

\section{Pendahuluan}

Keberhasilan suatu organisasi dipengaruhi oleh kinerja dari sumber daya manusia yang dimiliki. Sumber daya manusia atau yang biasa disebut karyawan atau pegawai merupakan kunci keberhasilan perusahaan. Pengelolaan sumber daya manusia yang baik akan mendorong organisasi atau perusahaan kea rah pencapaian tujuan yang telah ditetapkan (Sofyandi, 2008:116).

Hasil kerja yang dicapai oleh seseorang dalam melakukan tugas sesuai dengan tanggung jawab yang diberikan. Organisasi memegang peranan penting dalam mencapai tujuan dan keberhasilan perusahaan. Tujuan perusahaan dapat tercapai dengan sumber daya yang mampu meningkatkan produktivitas kerja guna peningkatan kinerja, pendapatan dan keuntungan perusahaan.

Karyawan yang mengalami gangguan produktivitas dan kesehatan, maka kinerja perusahaan akan terganggu. Kinerja dapat terganggu disebabkan oleh beberapa faktor antara lain kurang puas akan hasil kerja yang telah dicapai, karyawan kurang atau tidak memiliki motivasi, ataupun karena tekanan yang sedang dihadapi oleh karyawan tersebut 
sehingga menimbulkan dampak stress dalam bekerja.

Banyak faktor yang dapat meningkatkan kinerja sumber daya manusia yang baik di perusahaan. Diantaranya adalah kepuasan kerja, fasilitas kerja dan juga stress kerja. Menurut Hasibuan (2003:202), tolak ukur tingkat kepuasan yang mutlak tidak ada, karena setiap sumber daya manusia berbeda-beda standard kepuasannya. Pegawai yang memiliki kepuasan di dalam pekerjaannya ditandai dengan rendahnya tingkat absensi, tingkat perputaran pegawai yang rendah, dan produktivitas yang tinggi.

Fasilitas kerja merupakan faktor yang dapat mempengaruhi kinerja sumber daya manusia. Menurut Husnan (2002;48), fasilitas kerja merupakan sarana dan prasarana yang diperlukan untuk membantu karyawan agar lebih mudah menyelesaikan pekerjaan sehingga dapat meningkatkan kinerjanya.

Menurut Robins (2007:43), kinerja sumber daya manusia dipengaruhi oleh stress kerja, dimana stress kerja merupakan kondisi yang muncul dari interaksi antara pegawai dengan pekerjaan serta dikarakteristikkan oleh perubahan manusia yang memaksa mereka untuk menyimpang dari fungsi normal mereka. Gejala stress kerja ini dapat dilihat dari emosi yang tidak stabil, perasaan tidak tenang, suka menyendiri, sulit tidur, merokok yang berlebihan, tidak bisa rileks, cemas, tegang, gugup, tekanan darah meningkat, dan mengalami gangguan pencernaan.

Batalyon Kaveleri 6/Naga Karimata (Yonkav 6/Serbu) Kodam I Bukit Barisan adalah sebuah pasukan kaveleri Tentara Nasional Indonesia (TNI) yang dibentuk pada 18 Agustus 1954 dan bermarkas di Padang Bulan Medan Sumatera Utara. Yonkav 6/Serbu dibentuk berdasarkan Surat Keputusan Panglima Teritorium I No. 0134/PTT I/1954 Tanggal 18 April 1954, maka bertempat di lapangan Garuda diadakanlah peresmian berdirinya Eskadron Kaveleri V. Adapun tugas pokok Batalyon Kavaleri 6/Naga Karimata adalah melaksanakan operasi pertempuran darat dengan menggunakan kendaraan lapis baja dan pelaksanaan tugas lainnya dalam rangka mendukung tugas pokok Kodam I/BB.

Setiap personil Yonkav 6/NK Kodam I Bukit Barisan akan dinilai kinerja. Mereka diharapkan dapat memberikan kinerja yang tinggi bagi kesatuannya. Dalam rangka mencapai kinerja yang tinggi ada beberapa faktor yang mempengaruhinya, diantara factorfaktor tersebut yang menurut pengamatan peneliti adalah berkenaan dengan kepuasan kerja, fasilitas kerja dan stress kerja.

Setiap sumber daya manusia yang dimiliki oleh suatu organisasi harus memiliki kepuasan kerja yang tinggi agar dapat mempengaruhi kinerja sumber daya manusia tersebut. Berdasarkan hasil bincang-bincang peneliti dengan beberapa orang personil Yonkav 6/NK Kodam I BB ini mereka masih merasa belum memiliki kepuasan terhadap pekerjaan mereka, hal ini dapat dilihat dari tingginya jumlah personil yang absen setiap minggunya

Selanjutnya faktor lain yang masih dirasakan belum memadai bagi personil Yonkav 6/NK Kodam I Bukit Barisan ini adalah berkenaan dengan fasilitas kerja. Banyak fasilitas kerja yang rusak belum diperbaiki dan hal ini membuat pekerjaan mereka kadang harus ditunda karena fasilitas belum diperbaiki atau sedang diperbaiki.

Selanjutnya faktor lain yang berpengaruh terhadap kinerja personil Yonkav 6/NK Kodam I Bukit Barisan ini adalah tingginya stress kerja yang mereka hadapi. Karena tugas-tugas yang mereka jalankan sebagai penjaga kesatuan dan keamanan wilayah di Republik Indonesia maka mereka selalu harus waspada dan mencurigai setiap ada sesuatu hal yang menurut mereka mencurigakan yang mengancam stabilitas kesatuan dan keamanan wilayah di Republik Indonesia ini, sejalan dengan uraian di atas, maka tujuan yang hendak di capai pada penelitian ini adalah untuk menganalisis :

a. Pengaruh kepuasan kerja terhadap kinerja personil Yonkav 6/NK Kodam I Bukit Barisan.

b. Pengaruh fasilitas kerja terhadap kinerja personil Yonkav 6/NK Kodam I Bukit Barisan.

c. Pengaruh stress kerja terhadap kinerja personil Yonkav 6/NK Kodam I Bukit Barisan.

d. Pengaruh kepuasan kerja, fasilitas kerja dan stress kerja secara simultan terhadap kinerja personil Yonkav 6/NK Kodam I Bukit Barisan.

\section{METODE PENELITIAN}

\subsection{Lokasi Penelitian}

Adapun yang menjadi lokasi atau tempat penelitian ini adalah Pleton I Yonkav 6/NK KODAM I Bukit Barisan Jalan Bunga Teratai 
Kelurahan Asam Kumbang Kecamatan Medan Selayang.

\subsection{Populasi dan Sampel}

Populasi adalah generalisasi dari keseluruhan subjek dan objek penelitian yang ada. Pada penelitian ini yang menjadi populasi adalah seluruh Personil Pleton I Yonkav 6/NK KODAM I Bukit Barisan yang berjumlah 50 orang.

Penelitian ini tidak menggunakan penelitian sampel tetapi menggunakan penelitian populasi karena jumlah populasi kurang dari 100 orang, hal ini sesuai apa yang dinyatakan Arikunto (2002) yang menyatakan bahwa dalam menarik sampel yaitu apabila subjeknya kurang dari 100 orang, maka lebih baik diambil semua sehingga penelitiannya merupakan penelitian populasi. Selanjutnya jika jumlahnya lebih dari 100 orang, maka diambil $10 \%-15 \%$ atau $20 \%$ $25 \%$ atau lebih, oleh karena itu penelitian ini mengambil seluruh populasi yang ada untuk dijadikan sebagai responden pada penelitian ini.

\subsection{Defenisi Operasional}

Defenisi operasional bertujuan untuk mendeteksi sejauh mana variabel pada satu atau lebih faktor lain dan juga untuk mempermudah dalam membahas penelitian yang akan dilakukan. Paradigma ganda dengan tiga variabel bebas (independent variable) dan satu variabel terikat (dependent variable), yang termasuk variabel independen yaitu: Kepuasan Kerja, Fasilitas Kerja dan Stres Kerja sedangkan variabel dependen yaitu Kinerja Pegawai.

\subsection{Teknik Analisis Data \\ 2.4.1. Uji Validitas}

Validitas menunjukkan ukuran yang benarbenar mengukur apa yang akan diukur. Jadi dapat dikatakan semakin tinggi validitas suatu alat test, maka alat test tersebut semakin mengenai pada sasarannya, atau semakin menunjukkan apa yang seharusnya diukur. Suatu test dapat dikatakan mempunyai validitas tinggi apabila test tersebut menjalankan fungsi ukurnya, atau memberikan hasil ukur sesuai dengan makna dan tujuan diadakannya test tersebut. Jika peneliti menggunakan kuesioner di dalam pengumpulan data penelitian, maka butir pernyataan-butir pernyataan yang disusun pada kuesioner tersebut merupakan alat test yang harus mengukur apa yang menjadi tujuan penelitian.
Salah satu cara untuk menghitung validitas suatu alat test yaitu dengan melihat daya pembeda butir pernyataan . Daya pembeda butir pernyataan adalah metode yang paling tepat digunakan untuk setiap jenis test. Daya pembeda butir pernyataan dalam penelitian ini dilakukan dengan cara: "korelasi butir pernyataan-total". Korelasi butir pernyataantotal yaitu konsistensi antara skor butir pernyataan dengan skor secara keseluruhan yang dapat dilihat dari besarnya koefisien korelasi antara setiap butir pernyataan dengan skor keseluruhan, yang dalam penelitian ini menggunakan koefisien korelasi rank Spearman yaitu :

$$
\mathrm{r}_{\mathrm{s}}=\frac{\sum \mathrm{R}(\mathrm{X}) \mathrm{R}(\mathrm{Y})-\mathrm{n}\left(\frac{\mathrm{n}+1}{2}\right)^{2}}{\sqrt{\left(\sum(\mathrm{R}(\mathrm{X}))^{2}-\mathrm{n}\left(\frac{\mathrm{n}+1}{2}\right)^{2}\right)\left(\sum(\mathrm{R}(\mathrm{Y}))^{2}-\mathrm{n}\left(\frac{\mathrm{n}+1}{2}\right)^{2}\right)}}
$$

$\mathrm{R}(\mathrm{X})$ : Ranking skor butir pernyataan

$\mathrm{R}(\mathrm{Y})$ : Ranking dari total jumlah skor keseluruhan butir pernyataan.

n : jumlah sampel untuk uji validitas.

Bila koefisien korelasi untuk seluruh butir pernyataan telah dihitung, perlu ditentukan angka terkecil yang dapat dianggap cukup “ tinggi "sebagai indikator adanya konsistensi antara skor butir pernyataan dan skor keseluruhan. Dalam hal ini tidak ada batasan yang tegas. Prinsip utama pemilihan butir pernyataan dengan melihat koefisien korelasi adalah mencari harga koefisien yang setinggi mungkin dan menyingkirkan setiap butir pernyataan yang mempunyai korelasi negatif (-) atau koefisien yang mendekati nol $(0,00)$. Biasanya dalam pengembangan dan penyusunan skala-skala psikologi, digunakan harga koefisien korelasi yang minimal sama dengan 0,30 (Azwar, 1997: 158).

\subsubsection{Uji Reliabilitas}

Reliabilitas artinya adalah tingkat keterpercayaan hasil suatu pengukuran. Pengukuran yang memiliki reliabilitas tinggi, yaitu pengukuran yang mampu memberikan hasil ukur yang terpercaya (reliabel). Reliabilitas merupakan salah satu ciri atau karakter utama instrumen pengukuran yang baik. Kadang-kadang reliabilitas disebut juga sebagai keterpercayaan, keterandalan, keajegan, konsistensi, kestabilan, dan sebagainya, namun ide pokok dalam konsep reliabilitas adalah sejauh mana hasil suatu pengukuran dapat dipercaya, artinya sejauh mana skor hasil 
pengukuran terbebas dari kekeliruan pengukuran (measurement error).

Berdasarkan skala pengukuran dari butir pernyataan pernyataan maka teknik perhitungan koefisien reliabilitas yang digunakan adalah koefisien realibilitas Alpha-Cronbach dengan rumus sebagai berikut :

$$
\alpha=\frac{\mathrm{k}}{\mathrm{k}-1}\left(1-\frac{\sum_{\mathrm{i}=1}^{\mathrm{k}} \mathrm{S}_{\mathrm{i}}^{2}}{\mathrm{~S}^{2} \text { total }}\right)
$$

dimana : $\mathrm{k}$ adalah banyaknya butir pernyataan. $\mathrm{S}_{\mathrm{i}}{ }^{2}$ adalah varians dari skor butir pernyataan kei

$\mathrm{S}_{\text {total }}^{2}$ adalah varians dari total skor keseluruhan butir pernyataan

Sedangkan rumus varians yang digunakan adalah :

$$
S^{2}=\frac{1}{(n-1)} \sum_{i=1}^{n}\left(x_{i}-\bar{x}\right)^{2}
$$

dimana :

$\mathrm{S}^{2}=$ varians

$\mathrm{n}=$ banyaknya responden

$x_{i}=$ skor yang diperoleh responden ke-i

$\bar{x}=$ rata-rata $\quad($ Azwar, 1997)

Setelah nilai koefisien reliabilitas diperoleh, maka perlu ditetapkan suatu nilai koefisien reliabilitas paling kecil yang dianggap reliabel. Dimana disarankan bahwa koefisien reliabilitas antara 0,70 - 0,80 cukup baik untuk tujuan penelitian dasar (Kaplan-Saccuzzo 1993: 126).

\subsection{Uji Asumsi Klasik}

Model dan teknik analisis data yang digunakan pada penelitian ini adalah Regresi Linear Berganda (Multiple Regression Analysis), menurut Gujarati (2007) menyatakan bahwa "sebelum dilakukan suatu uji regresi linear berganda terlebih dahulu dilakukan uji kesahihan dan keajegan data melalui uji asumsi klasik".

Ghozali (2005) menyebutkan terdapat 4 (empat) uji yang dilakukan menguji asumsi klasik, yaitu: uji multikolinearitas, uji autokorelasi, uji heteroskasdisitas dan uji normalitas.

\subsection{Uji Hipotesis}

\subsubsection{Uji t (Parsial)}

Digunakan untuk menguji signifikansi hubungan antara variabel $\mathrm{x}$ dengan variabel $\mathrm{y}$, apakah variabel $\mathrm{X}_{1}, \mathrm{X}_{2}$, dan $\mathrm{X}_{3}$ benar-benar berpengaruh terhadap variabel $Y$ dapat dihitung dengan menggunakan rumus:

$$
\text { Uji } t=\frac{r \sqrt{n-2}}{\sqrt{1-r^{2}}}
$$

Dimana:

r : Korelasi

n : Jumlah sampel

Jika : $t_{\text {hitung }}>t_{\text {tabel }}$ Hipotesis diterima

$t_{\text {hitung }}<$ ttabel Hipotesis ditolak

a. Jika $t_{\text {hitung }}>t_{\text {tabel }}$ dan probabilitas (nilai signifikan) $<$ tingkat signifikansi 5\% $(\alpha=$ $0,05)$ maka Ha diterima dan Ho ditolak berarti ada pengaruh yang signifikan dari masing-masing variabel independen terhadap variabel dependen.

b. Jika $t_{\text {hitung }}<t_{\text {tabel }}$ dan probabilitas (nilai signifikansi) $>$ tingkat signifikansi 5\% $(\alpha=$ $0,05)$ maka Ho diterima dan $\mathrm{Ha}$ ditolak berarti tidak ada pengaruh yang signifikan dari masing-masing variabel independen terhadap variabel dependen. Dimana t tabel ditentukan dengan mencari derajat bebasnya yaitu $\mathrm{df}=\mathrm{N}-\mathrm{k}$.

\subsubsection{Uji F (Simultan)}

Uji F secara simultan adalah pengujian secara bersama-sama antara variabel bebas (independent) yang mempunyai hubungan atau pengaruh terhadap variabel terikat (dependent) dengan rumus berikut:

$$
F \text { hit }=\frac{R^{2} /(k-1)}{\left(l-R^{2}\right)(n-3)}
$$

Dimana:

$\mathrm{R}$ : Koefisien korelasi

n : Jumlah sampel

$\mathrm{k}$ : Jumlah variabel

Jika : $\mathrm{F}_{\text {hitung }}>\mathrm{F}_{\text {tabel }}$ maka Hipotesis penelitian diterima

$$
\mathrm{F}_{\text {hitung }}<\mathrm{F}_{\text {tabel }} \quad \text { maka Hipotesis }
$$

penelitian ditolak

a. Jika $\mathrm{F}_{\text {hitung }}>\mathrm{F}_{\text {tabel }}$ dan probabilitas (nilai signifikan $)<$ tingkat signifikansi 5\% ( $\alpha=$ 0,05) maka Ha diterima dan Ho ditolak berarti ada variabel independen secara bersama-sama mempunyai pengaruh yang signifikan terhadap variabel dependen.

b. Jika $\mathrm{F}_{\text {hitung }}<\mathrm{F}_{\text {tabel }}$ dan probabilitas (nilai signifikansi) $>$ tingkat signifikansi 5\% $(\alpha=$ $0,05)$ maka Ho diterima dan $\mathrm{Ha}$ ditolak berarti ada variabel independen secara bersama-sama tidak mempunyai pengaruh 
yang signifikan terhadap variabel dependen. Dimana $\mathrm{F}$ tabel ditentukan dengan mencari derajat bebasnya yaitu df $1=\mathrm{k}-1$ dan $\mathrm{df} 2=\mathrm{N}$ $\mathrm{k}$, dimana $\mathrm{N}=$ jumlah sampel dan $\mathrm{k}=$ jumlah variabel.

\subsection{Uji Determinan $\left(\mathbf{R}^{2}\right)$}

Selanjutnya untuk mengetahui seberapa besar kontribusi variabel bebas terhadap variabel terikat, yaitu Kepuasan Kerja, Fasilitas Kerja dan Stres Kerja Terhadap Kinerja d personil Pleton I Yonkav 6/NK KODAM I Bukit Barisan dapat digunakan rumus sebagai determinasi sebagai berikut (Sugiyono, 2004: 190)

Keterangan :

$$
\mathbf{D}=\mathbf{R}^{2} \times 100 \%
$$

$\mathrm{D}=$ Determinan

$\mathrm{R}=$ Regresi linier

\section{Analisi dan Pembahasan}

\subsection{Uji Validitas}

Uji validitas dilakukan untuk mengetahui apakah alat ukur yang telah disusun dapat digunakan untuk mengukur apa yang hendak diukur secara tepat. Validitas suatu instrumen menggambarkan tingkat kemampuan alat ukur yang digunakan untuk mengungkapkan sesuatu yang menjadi sasaran pokok pengukuran. Bila instrumen tersebut mampu untuk mengukur variabel yang diukur maka disebut sebagai valid, dan sebaliknya apabila tidak mampu untuk mengukur variabel yang diukur maka akan disebut tidak valid.

Pengujian validitas instrumen menggunakan Analyst Correlate Bivariate untuk mencari correlation coefficient dari Product Moment Pearson dengan SPSS. Kemudian dibandingkan dengan nilai $r_{\text {table }}$ untuk $\alpha=0.05$ dengan derajat kebebasan $(\mathrm{dk}=\mathrm{n}-2)$ sehingga didapat $\mathrm{r}_{\text {table. }}$. Untuk butir pernyataan dengan nilai koefisien korelasi ( $\left.r_{\text {hitung }}\right)>r_{\text {table }}$ maka butir pernyataan tersebut dinyatakan valid.

Karena jumlah responden yang digunakan untuk uji validitas sebanyak 50 orang, maka nilai $r_{\text {tabel }}$ dapat ditentukan dari: $\mathbf{d k}=\mathbf{n}-\mathbf{2}=\mathbf{5 0 - 2}$ $=48$

Nilai $r$ tabel dengan $\mathrm{dk}=48$ adalah 0,254 . Jadi, jika $r_{\text {hitung }}>0,254$ maka item pertanyaan dinyatakan valid.
Table 1

Hasil Uji Validitas Variabel $\left(\mathrm{X}_{1}\right)$ Kepuasan

\begin{tabular}{|c|c|c|c|}
\hline item & $\mathbf{r}_{\text {hitung }}$ & $\mathbf{r}_{\text {tabel }}$ & Keterangan \\
\hline 1 & 0,405 & 0,254 & Valid \\
\hline 2 & 0,294 & 0,254 & Valid \\
\hline 3 & 0,901 & 0,254 & Valid \\
\hline 4 & 0,901 & 0,254 & Valid \\
\hline 5 & 0,697 & 0,254 & Valid \\
\hline 6 & 0,405 & 0,254 & Valid \\
\hline 7 & 0,483 & 0,254 & Valid \\
\hline 8 & 0,901 & 0,254 & Valid \\
\hline 9 & 0,338 & 0,254 & Valid \\
\hline 10 & 0,294 & 0,254 & Valid \\
\hline
\end{tabular}

Sumber: SPSS (2019)

Table 2

Hasil Uji Validitas Variabel $\left(\mathrm{X}_{2}\right)$ Fasilitas

Kerja

\begin{tabular}{|c|c|c|c|}
\hline item & $\mathbf{r}_{\text {hitung }}$ & $\mathbf{r}_{\text {tabel }}$ & Keterangan \\
\hline 1 & 0,415 & 0,254 & Valid \\
\hline 2 & 0,433 & 0,254 & Valid \\
\hline 3 & 0,834 & 0,254 & Valid \\
\hline 4 & 0,834 & 0,254 & Valid \\
\hline 5 & 0,660 & 0,254 & Valid \\
\hline 6 & 0,415 & 0,254 & Valid \\
\hline 7 & 0,447 & 0,254 & Valid \\
\hline 8 & 0,834 & 0,254 & Valid \\
\hline 9 & 0,350 & 0,254 & Valid \\
\hline 10 & 0,433 & 0,254 & Valid \\
\hline
\end{tabular}

Sumber: SPSS (2019)

Tabel 3

Hasil Uji Validitas Variabel $\left(\mathrm{X}_{3}\right)$ Stres Kerja

\begin{tabular}{|c|c|c|c|}
\hline item & $\mathbf{r}_{\text {hitung }}$ & $\mathbf{r}_{\text {tabel }}$ & Keterangan \\
\hline 1 & 0,391 & 0,254 & Valid \\
\hline 2 & 0,629 & 0,254 & Valid \\
\hline 3 & 0,741 & 0,254 & Valid \\
\hline 4 & 0,741 & 0,254 & Valid \\
\hline 5 & 0,698 & 0,254 & Valid \\
\hline 6 & 0,391 & 0,254 & Valid \\
\hline 7 & 0,314 & 0,254 & Valid \\
\hline 8 & 0,741 & 0,254 & Valid \\
\hline
\end{tabular}




\begin{tabular}{|c|c|c|c|}
\hline item & $\mathbf{r}_{\text {hitung }}$ & $\mathbf{r}_{\text {tabel }}$ & Keterangan \\
\hline 9 & 0,284 & 0,254 & Valid \\
\hline 10 & 0,629 & 0,254 & Valid \\
\hline
\end{tabular}

Sumber: SPSS (2019)

Tabel 4

Hasil Uji Validitas Variabel (Y) Kinerja Personil

\begin{tabular}{|c|c|c|c|}
\hline item & $\mathbf{r}_{\text {hitung }}$ & $\mathbf{r}_{\text {tabel }}$ & Keterangan \\
\hline 1 & 0,728 & 0,254 & Valid \\
\hline 2 & 0,621 & 0,254 & Valid \\
\hline 3 & 0,428 & 0,254 & Valid \\
\hline 4 & 0,728 & 0,254 & Valid \\
\hline 5 & 0,446 & 0,254 & Valid \\
\hline 6 & 0,621 & 0,254 & Valid \\
\hline 7 & 0,621 & 0,254 & Valid \\
\hline
\end{tabular}

Tabel 5

Hasil Uji Realibilitas

\begin{tabular}{|l|c|c|c|}
\hline \multicolumn{1}{|c|}{ Variable } & $\begin{array}{c}\text { Cronbach's } \\
\text { Alpha }\end{array}$ & N of Items & Reabilitas Status \\
\hline Kepuasan Kerja $\left(\mathrm{X}_{1)}\right.$ & 0,781 & 10 & Reliabel \\
\hline Fasilitas Kerja $\left(\mathrm{X}_{2)}\right.$ & 0,775 & 10 & Reliabel \\
\hline Disiplin Kerja $\left(\mathrm{X}_{3)}\right.$ & 0,760 & 10 & Reliabel \\
\hline Kinerja Personil $(\mathrm{Y})$ & 0,796 & 10 & Reliabel \\
\hline
\end{tabular}

Sumber: SPSS (2019)

Berdasarkan tabel 5 diatas terlihat bahwa nilai cronbach alpha seluruh variabel berkisar antara 0 sampai 1 dan lebih cenderung mendekati angka 1, dengan demikian keseluruhan item dalam instrumen pengukuran dapat kategorikan sangat reliabel.

\subsection{Uji Asumsi Klasik}

\subsection{Uji Normalitas}

Pengujian normalitas data bertujuan untuk melihat normal tidaknya sebaran data yang akan dianalisis. Model regresi yang baik adalah distribusi normal atau mendekati normal. Untuk melihat normalitas data ini digunakan pendekatan grafik yaitu Normality Probability Plot. Deteksi normalitas dengan melihat penyebaran data (titik) pada sumbu diagonal dari grafik. Menurut Santoso (2004: 214), dasar pengambilan keputusan adalah:

a. Jika data menyebar disekitar garis diagonal dan mengikuti arah garis diagonal, maka model regresi memenuhi asumsi normalitas.

b. Jika data menyebar jauh dari garis diagonal dan atau tidak mengikuti arah garis diagonal, maka model regresi tidak memenuhi asumsi normalitas.

\begin{tabular}{|c|c|c|c|}
\hline 8 & 0,583 & 0,254 & Valid \\
\hline 9 & 0,641 & 0,254 & Valid \\
\hline 10 & 0,583 & 0,254 & Valid \\
\hline
\end{tabular}

Sumber : SPSS (2019)

Berdasarkan tabel 5.44 hingga 5.47 sebahagian besar pernyataan dalam setiap variabel memiliki nilai coreccted item correlation $\left(\mathrm{r}_{\text {hitung }}\right)$ lebih besar dari $\mathrm{r}_{\text {tabel }}$.

\subsection{Uji Realibilitas}

Uji ini dilakukan untuk melihat konsistensi dari indikator yang digunakan untuk mengukur variabel. Tingkat konsistensi ini dilihat dari konsistensi jawaban responden, dalam kondisi dan keadaan apapun. Hasil uji realibilitas ini dapat dilihat pada tabel berikut ini:
Pada output SPSS bagian normal P-P Plot of Regresion Standardized Residual, dapat dijelaskan bahwa data-data (titik-titik) cenderung lurus mengikuti garis diagonal sehingga data dalam penelitian ini cenderung berdistribusi normal, seperti terlihat pada gambar dibawah ini.

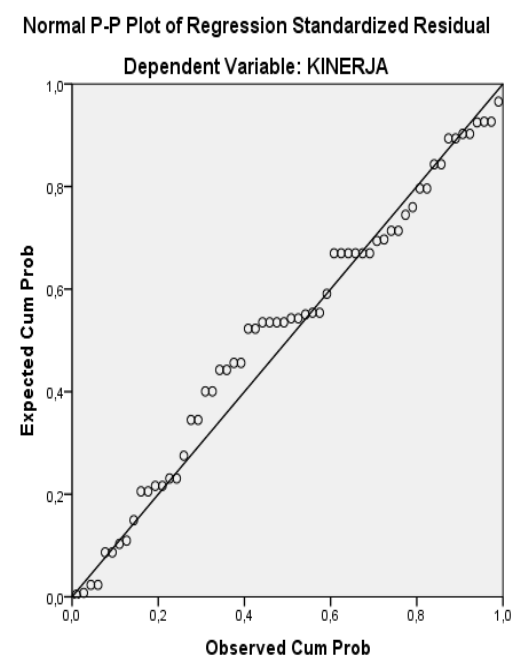

Gambar 1 Normalitas Data 


\subsection{Uji Heteroskedastisitas}

Pengujian heteroskedastisitas bertujuan untuk melihat apakah dalam sebuah model regresi terjadi ketidaksamaan varians dari residual yang merupakan suatu pengamatan ke pengamatan yang lainnya. Jika varians dari residual yang merupakan suatu pengamatan ke pengamatan yang lain bernilai tetap, maka hasil data disebut homoskedastisitas dan jika varians berbeda atau bernilai tidak tetap maka disebut heteroskedastisitas. Model regresi yang baik adalah model yang bernilai tetap atau homoskedastisitas atau tidak terjadi heteroskedastisitas.

Deteksi heteroskedastisitas dilakukan dengan cara melihat ada tidaknya pola tertentu pada data yang diolah. Menurut Santoso (2004: 208), dasar pengambilan keputusannya adalah:

a. Jika pola tertentu seperti titik-titik yang ada membentuk suatu pola tertentu yang teratur, maka terdapat situasi heteroskedastisitas.

b. Jika tidak ada pola yang jelas, serta titik-titik menyebar diatas dan dibawah angka nol pada sumbu Y, maka tidak terjadi heteroskedastisitas.

Pada output SPSS dibagian Scatrerplot, terlihat titk-titik menyebar secara acak, tidak membentuk sebuah pola tertentu yang jelas, serta tersebar baik diatas maupun dibawah angka nol pada sumbu Y. Hal ini berarti tidak terjadi heterskedastisitas pada model regresi, sehingga model regresi layak dipakai. Pola Scatterplot dapat dilihat pada gambar dibawah ini.

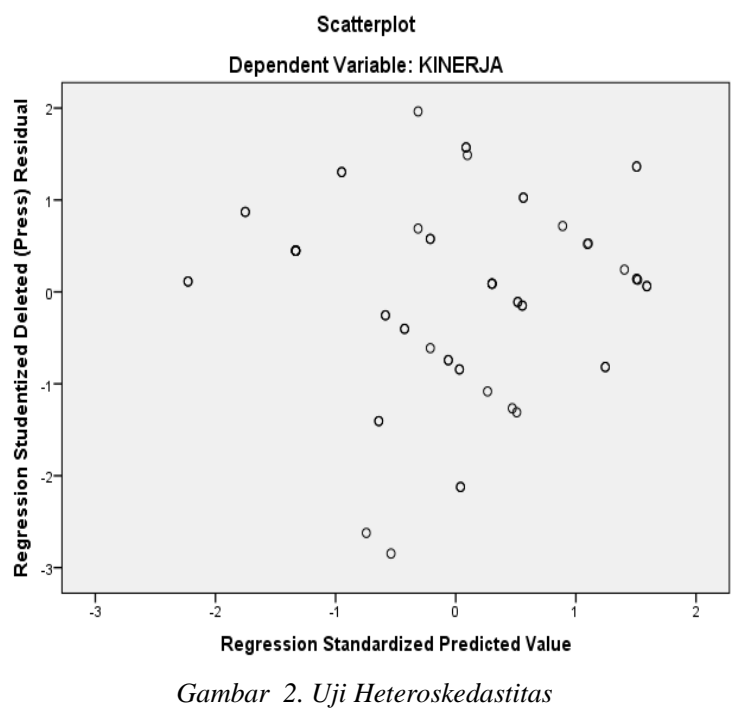

\subsection{Uji Multikolinearitas}

Pengujian multikolinearitas dilakukan untuk melihat apakah pada model regresi ditemukan adanya korelasi antara variabel bebas. Jika terjadi korelasi, maka dinamakan terdapat problem multikolinearitas. Cara mendeteksinya adalah dengan melihat nilai Variance Inflation Factor (VIF). Menurut Santoso (2004: 203), pada umumnya jika VIF lebih besar dari 5, maka variabel bebas tersebut mempunyai persoalan multikolinearitas dengan variabel bebas lainnya.

Pada ouput SPSS bagian Coefficient, semua angka VIF berada dibawah 5, hal ini menunjukan tidak terjadi multikolinearitas, seperti dapat dilihat pada tabel dibawah ini.

Tabel 6

Uji Multikolinearitas

\begin{tabular}{|c|c|c|c|}
\hline \multicolumn{4}{|c|}{ Coefficients ${ }^{\mathrm{a}}$} \\
\hline & \multirow{2}{*}{ Model } & \multicolumn{2}{|c|}{ Collinearity Statistics } \\
\hline & & Tolerance & VIF \\
\hline \multirow{4}{*}{1} & (Constant) & & \\
\hline & KEPUASAN KERJA & ,837 & 1,194 \\
\hline & FASILITAS KERJA & 644 & 1,553 \\
\hline & STRES KERJA & 645 & 1,551 \\
\hline
\end{tabular}

Sumber: Out Put SPSS (2019)

\subsection{Pengujian Hipotesis}

Pada evaluasi data ini penulis akan melakukan pengujian hipotesis, baik secara partial ataupun secara simultan. Selanjutnya untuk mempermudah dalam evaluasi data ini, maka penulis mencari niali-nilai yang dibutuhkan dengan menggunakan perangkat lunak komputer yaitu program SPSS V.20.00 for windows dengan hasil data sebagai berikut: 
Tabel 7

Hasil Uji Statistik Keofesien Regresi

\begin{tabular}{|c|c|c|c|c|c|}
\hline \multirow[t]{2}{*}{ Model } & \multicolumn{2}{|c|}{$\begin{array}{c}\text { Unstandardized } \\
\text { Coefficients }\end{array}$} & $\begin{array}{l}\text { Standardized } \\
\text { Coefficients }\end{array}$ & \multirow[t]{2}{*}{$\mathrm{t}$} & \multirow[t]{2}{*}{ Sig. } \\
\hline & B & Std. Error & Beta & & \\
\hline (Constant) & 21,065 & 3,703 & & 5,688 &, 000 \\
\hline $\begin{array}{l}\text { KEPUASAN } \\
\text { KERJA }\end{array}$ & ,127 & ,073 & , 184 & 1,740 & ,087 \\
\hline $\begin{array}{l}\text { FASILITAS } \\
\text { KERJA }\end{array}$ & , 164 & ,076 & 258 & 2,139 & ,037 \\
\hline STRES KERJA &,- 298 & ,088 & ,407 & 3,374 & ,001 \\
\hline
\end{tabular}

Sumber: Out Put SPSS (2019)

Berdasarkan tabel 5.50 diatas dapat dibuat persamaan regresi sebagai berikut:

$$
Y=21,065+0,127 X_{1}+0,164 X_{2}-0,298 X_{3}+\varepsilon
$$

Persamaan diatas dijelaskan bahwa koefesien $\mathrm{X}_{1}$ (Kepuasan Kerja) mempunyai nilai positif yaitu 0,127 , hal ini menunujukan bahwa variabel Kepuasan Kerja mempunyai pengaruh positif terhadap Kinerja Personil pada Pleton I YONKAV 6/NK KODAM I BUKIT BARISAN . Jadi bila Kepuasan Kerja sesuai dengan tugasnya maka akan berdampak positif terhadap kinerja personil pada Pleton I YONKAV 6/NK KODAM I BUKIT BARISAN. Berdasarkan persamaan diatas bahwa koefesien $\mathrm{X}_{2}$ (Fasilitas Kerja) juga memiliki nilai positif yaitu 0,164 . Hal ini menunjukan bahwa variabel fasilitas kerja mempunyai pengaruh positif terhadap kinerja personil pada Pleton I YONKAV 6/NK KODAM I BUKIT BARISAN . Berdasarkan persamaan diatas bahwa koefesien $\mathrm{X}_{3}$ (Stres Kerja) juga memiliki nilai positif yaitu 0,298 . $\mathrm{Hal}$ ini menunjukan bahwa variabel stress kerja pegawai mempunyai pengaruh negatif terhadap kinerja personil pada Pleton I YONKAV 6/NK KODAM I BUKIT BARISAN .

Hal ini berarti jika kepuasan kerja, fasilitas kerja dan stress kerja diperhatikan akan berdampak baik terhadap kinerja personil pada Pleton I YONKAV 6/NK KODAM I BUKIT BARISAN .

\subsection{Pengujian Hipotesis Secara Simultan (Uji F)}

Hasil pengujian hipotesis berpengaruh secara simultan antara kepuasan kerja, fasilitas kerja dan stress kerja terhadap kinerja personildapat dilihat pada tabel dibawah ini.

Tabel 8

Hasil Uji Statistik Secara Simultan

\begin{tabular}{|l|r|r|r|r|r|}
\hline Model & Sum of Squares & \multicolumn{1}{c|}{ df } & Mean Square & \multicolumn{1}{c|}{ F } & \multicolumn{1}{c|}{ Sig. } \\
\hline \multirow{2}{*}{$\begin{array}{l}\text { Regression } \\
\text { Residual }\end{array}$} & 37,479 & 3 & 12,493 & 16,856 &, $000^{\mathrm{b}}$ \\
Total & 41,504 & 56 &, 741 & & \\
\hline
\end{tabular}

Pada tabel 5.51 diatas terlihat bahwa nilai $\mathrm{F}_{\text {hitung }}$ adalah 16,858 dan nilai signifikansi 0,000.

Diketahui nilai $\mathrm{F}_{\text {tabel }}$ dengan tingkat kepercayaan $95 \%(\alpha: 0,05)$ adalah 2,760. Oleh karena itu nilai $\mathrm{F}_{\text {hitung }}>\mathrm{F}_{\text {tabel }}(16,856>2,760)$ maka $\mathrm{H}_{0}$ ditolak dan menerima hipotesis dalam penelitian ini yaitu bahwa kepuasan kerja, fasilitas kerja dan stress kerja secara simultan berpengaruh signifikan terhadap kinerja personil pada Pleton I YONKAV 6/NK KODAM I BUKIT BARISAN .

\subsection{Pengujian Hipotesis Secara Parsial (Uji t)}




\subsubsection{Pengaruh Kepuasan Kerja (X1) Terhadap Kinerja Personil (Y)}

Tabel 9

Hasil Uji Parsial Variabel $\mathrm{X}_{1}$ Terhadap Y

\begin{tabular}{|c|c|c|c|c|c|}
\hline \multirow[t]{2}{*}{ Model } & \multicolumn{2}{|c|}{$\begin{array}{c}\text { Unstandardized } \\
\text { Coefficients }\end{array}$} & $\begin{array}{l}\text { Standardized } \\
\text { Coefficients }\end{array}$ & \multirow[t]{2}{*}{$\mathrm{t}$} & \multirow[t]{2}{*}{ Sig. } \\
\hline & $\mathrm{B}$ & Std. Error & Beta & & \\
\hline $\begin{array}{l}\text { KEPUASAN } \\
\text { KERJA }\end{array}$ & , 127 & ,073 & , 184 & 1,740 & 05, \\
\hline
\end{tabular}

Sumber: Out Put SPSS (2019)

Untuk mengetahui secara partial pengaruh kepuasan kerja terhadap kinerja personil dapat dilihat pada tebel 5.52 diatas. Berdasarkan tabel tersebut diperoleh nilai $t_{\text {hitung }}$ sebesar 1,740 dan nilai signifikansi 0,05 . Sedangkan nilai $t_{\text {tabel }}$ pada tingkat kepercayaan $95 \%(\alpha: 0,05)$ adalah 2,000 . Oleh karena itu nilai $t_{\text {hitung }}<t_{\text {tabel }}(1,740<$
2,000) maka $\mathrm{H}_{\mathrm{a}}$ ditolak dan menerima $\mathrm{H}_{0}$ hipotesis dalam penelitian ini yaitu variabel kepuasan kerja secara partial berpengaruh positif dan signifikan terhadap kinerja personil pada. Pleton I YONKAV 6/NK KODAM I BUKIT BARISAN .

\subsubsection{Pengaruh Fasilitas Kerja (X2) Terhadap Kinerja Personil (Y)}

Tabel 10

Hasil Uji Parsial Variabel $\mathrm{X}_{2}$ Terhadap $\mathrm{Y}$

\begin{tabular}{|l|r|r|r|r|r|}
\hline \multirow{2}{*}{ Model } & \multicolumn{2}{|c|}{$\begin{array}{c}\text { Unstandardized } \\
\text { Coefficients }\end{array}$} & $\begin{array}{l}\text { Standardized } \\
\text { Coefficients }\end{array}$ & \multirow{2}{*}{ T } & \multirow{2}{*}{ Sig. } \\
\cline { 2 - 4 } & \multicolumn{1}{c|}{ B } & Std. Error & \multicolumn{1}{c|}{ Beta } & \\
\hline $\begin{array}{l}\text { FASILITAS } \\
\text { KERJA }\end{array}$ &, 164 &, 076 &, 258 & 2,139 &, 037 \\
\hline
\end{tabular}

Sumber: Out Put SPSS (2019)

Untuk mengetahui secara partial pengaruh fasilitas kerja terhadap kinerja personil dapat dilihat pada tabel 5.53 diatas. Berdasarkan tabel tersebut diperoleh nilai $t_{\text {hitung }}$ sebesar 2,139 dan nilai signifikansi 0.037 . Sedangkan nilai $t_{\text {tabel }}$ pada tingkat kepercayaan $95 \%(\alpha: 0,05)$ adalah 2,000 . Oleh karena itu nilai $t_{\text {hitung }}>t_{\text {tabel }}(2,139$
>2,000) maka $\mathrm{H}_{0}$ ditolak dan menerima hipotesis dalam penelitian ini yaitu variabel fasilitas kerja secara partial berpengaruh positif dan signifikan terhadap kinerja personil pada Pleton I YONKAV 6/NK KODAM I BUKIT BARISAN .

\subsubsection{Pengaruh Stres Kerja (X3) Terhadap Kinerja Personil (Y)}

Tabel 11

Hasil Uji Parsial Variabel $\mathrm{X}_{3}$ Terhadap Y

\begin{tabular}{|c|r|r|r|r|r|}
\hline Model & \multicolumn{2}{|c|}{$\begin{array}{c}\text { Unstandardized } \\
\text { Coefficients }\end{array}$} & $\begin{array}{c}\text { Standardized } \\
\text { Coefficients }\end{array}$ & \multirow{2}{*}{ T } & \multirow{2}{*}{ Sig. } \\
\cline { 2 - 4 } & \multicolumn{1}{c|}{ B } & Std. Error & \multicolumn{1}{c|}{ Beta } & & \\
\hline STRES KERJA &,- 298 &, 088 &, 407 & 3,374 &, 001 \\
\hline
\end{tabular}

Untuk mengetahui secara partial pengaruh stress kerja terhadap kinerja personil dapat dilihat pada tabel 5.54 diatas. Berdasarkan tabel tersebut diperoleh nilai $t_{\text {hitung }}$ sebesar 3,374 dan nilai signifikansi 0,001 . Sedangkan nilai $t_{\text {tabel }}$ pada tingkat kepercayaan $95 \%(\alpha: 0,05)$ adalah 2,000 . Oleh karena itu nilai $t_{\text {hitung }}>t_{\text {tabel }}(3,374>$ 2,000) maka $\mathrm{H}_{0}$ ditolak dan menerima hipotesis dalam penelitian ini yaitu variabel stress kerja secara partial berpengaruh negatif dan signifikan terhadap kinerja personil pada Pleton I YONKAV 6/NK KODAM I BUKIT BARISAN .

\subsection{Uji Koefisien Determinasi $\left(\mathbf{R}^{2}\right)$}

Uji determinan adalah untuk mengetahui seberapa besar pengaruh variabel independent terhadap variabel dependent. Untuk melihat 
hasil uji determinan maka dapat diketahui nili $\mathrm{R}$ dilihat dibawah ini. Square atau koefesien determinasi dan dapat

Tabel 5.55. Model Summary

\begin{tabular}{|l|c|c|r|r|}
\hline Model & $\mathrm{R}$ & \multicolumn{1}{|c|}{ R Square } & Adjusted R Square & Std. Error of the Estimate \\
\hline 1 &, $689^{\mathrm{a}}$ &, 475 &, 446 &, 861 \\
\hline
\end{tabular}

Nilai R Square pada tabel diatas adalah 0,475 . Hal ini menunjukan bahwa $47,5 \%$ variabel kinerja personil pada Pleton I YONKAV 6/NK KODAM I BUKIT BARISAN dapat dijelaskan oleh variabel kepuasan kerja, fasilitas kerja dan stress kerja sedangkan sisanya sebesar $52,5 \%$ dipengaruhi oleh variabel lain yang tidak diteliti pada penelitian ini.

\section{Kesimpulan}

a. Kepuasan Kerja secara partial berpengaruh positif dan signifikan terhadap kinerja personil pada Pleton I YONKAV 6/NK KODAM I BUKIT BARISAN . dengan nilai $t_{\text {hitung }}<t_{\text {tabel }}(1,740<2,000)$.

b. Fasilitas Kerja secara partial berpengaruh positif dan signifikan terhadap kinerja personil pada Pleton I YONKAV 6/NK KODAM I BUKIT BARISAN dengan nilai $t_{\text {hitung }}>t_{\text {tabel }}(2,139>2,000)$.

c. Stres Kerja secara partial berpengaruh negative dan signifikan terhadap kinerja personil pada Pleton I YONKAV 6/NK KODAM I BUKIT BARISAN dengan nilai $t_{\text {hitung }}>t_{\text {tabel }}(3,374>2,000)$.

d. Kepuasan Kerja, Fasilitas Kerja dan Stres Kerja secara bersama-sama (simultan) berpengaruh signifikan terhadap kinerja personil pada Pleton I YONKAV 6/NK KODAM I BUKIT BARISAN dengan nilai $F_{\text {hitung }}>F_{\text {tabel }}(16,856>2,740)$.

e. Nilai R Square pada hasil penelitian adalah 0,475 . Hal ini menunjukan bahwa $47,5 \%$ variabel kinerja personil pada Pleton I YONKAV 6/NK KODAM I BUKIT BARISAN dapat dijelaskan oleh variabel rekrutmen, seleksi dan penempatan pegawai sedangkan sisanya sebesar $52,5 \%$ tidak dilakukan penelitian.

\section{DAFTAR PUSTAKA}

Ahmad, Ibrahim Abu Sinn (2008), Manajemen Syariah, Raja Grafindo Persada Jakarta
As'ad, M. 2003. Psikologi Industri. Yogyakarta : Liberty.

Devi Dayang Septiasari (2017), eJournal Administrasi Bisnis, 2017, 5 (1), 93-106, ISSN 2355-5408, ejournal.adbisnis.fisipunmul.ac.id, p.93-106

Dharma, S. (2004). Manajemen Kinerja : Falsafah, Teori, dan Penerapannya. Program Pascasarjana FISIP. Jakarta.

Fauzi, Usman (2014), eJournal Ilmu Administrasi Bisnis, 2014, 2 (3) : 172-185 ISSN 2355-5408 ejournal.ad.bisnis.fisip.unmul.ac.id

Flippo, Edwin B. Masud Moh (alih bahasa), (2001). Manajemen Personalia. Edisi Keenam. Jilid Kedua. Jakarta : Erlangga

Ghozali, Imam. (2005) SPSS, Universitas Diponegoro. Semarang

Gomes, Faustino Cardoso. (2000) Manajemen Sumber Daya Manusia. Edisi I. Yogyakarta, Andi Offset.

Hasibuan, Malayu S.P. (2008). Manajemen Sumber Daya Manusia, Edisi Revisi, Jakarta, PT. Bumi Aksara

Indriantoro, Nur, dan Supomo. (2002) Metodologi Penelitian. Edisi 1. Yogyakarta: Penerbit BPFE Yogyakarta

Koesmono, T H. (2005), Pengaruh Budaya Organisasi, Terhadap Motivasi dan Kepuasan Kerja Serta Kinerja Karyawan Pada Sub Sektor Industri Pengolahan Kayu Skala Menengah Di Jawa Timur, Jurnal Manajemen \& Kewirausahaan, Vol.7 No. 2

Khairul Anam dan Edy Rahardja (2017), Diponegoro Journal of Management, Vol. 6 No. 4 Tahun 2017, p.1-11, ISSN (online) 2337-3792.

Kuncoro, M. (2007) Metode Riset untuk Bisnis dan Ekonomi. Jakarta: Erlangga.

Wibowo. 2007. Manajemen Kinerja. PT. Raja Grafindo Parsada: Jakarta.

Lupiyaodi (2006), Manajemen Pemasaran Jasa, Edisi Kedua, Jakarta, Salemba Empat.

Mangkunegara, Anwar Prabu (2009), Evaluasi Kinerja SDM, Cetakan ke-4, Bandung, Rafika Aditama 
Mangkunegara, Anwar Prabu, (2005) Perilaku dan Budaya Organisasi, Cetakan Pertama, PT. Refika Aditama, Bandung.

Mas'ud (2004), Manajemen Stres, Jakarta, PT. Bumi Aksara

Mangkunegara, AP, (2005) Perilaku dan Budaya Organisasi, Cetakan Pertama, PT. Refika Aditama, Bandung.

Masrukhin dan Waridin, 2006. Pengaruh Motivasi Kerja, Kepuasan Kerja, Budaya Organisasi, dan Kepemimpinan Terhadap Kinerja Pegawai, EKOBIS, Vol. 7 No. 2.

Mathis, Robert L dan Jackson, John H, 2001, "Manajemen Sumberdaya Manusia," Buku 1, Salemba Empat Jakarta.

Moeheriono. 2009. Pengukuran Kinerja Berbasis Kompetensi. Jakarta : Ghalia Indonesia. Notoatmodjo, Soekidjo (2009). Pengembangan Sumber Daya Manusia. Cetakan 4. Jakarta: Rineka Cipta.

Putu Agus Yoga Ariawan dan A.A. Ayu Sriati (2018). E-Jurnal Manajemen UNUD Vol. 7 No. 2 2018, p.964-992, ISSN. 2302-8912

Rivai. V, dan Sagala. 2013. Manajemen Sumber Daya Manusia untuk Perusahaan, Penerbit PT. Raja Grafindo Persada, Jakarta.

Robbins, S P. 2006. Perilaku Organisasi : Konsep,Kontroversi,Aplikasi. Jakarta: Prenhallindo.

Ruky. 2003. Kepuasan dan Prestasi Karyawan. Tesis. Fakultas Ekonomi, Denpasar. Universitas Udayana.
Simamora, H. 2004. Manajemen Sumber Daya Manusia. Yogyakarta: Sekolah Tinggi Ilmu Ekonomi YKPN.

Sopiah. 2008. Perilaku Organisasi. Yogyakarta : CV andi ofsett.

Stefanus Andri Pratama, Muhammad Soe'oed Hakam, Gunawan Eko Nurtjahjono (2015), Jurnal Administrasi Bisnis (JAB) VOl. 25 No. 1 Agustus 2015

Sugiyono. 2004.Metode Penelitian Bisnis. Bandung : Alfabeta

Sugiyono. 2009. Statistika untuk Penelitian. Bandung : Alfabeta.

Sumarsono, S. 2003. Ekonomi Manajemen Sumber Daya Manusia dan Ketenagakerjaan. Jogyakarta : Graha Ilmu.

Sofyan (2004), Manajemen Produksi dan Operasi, Edisi Revisi, Lembaga Penerbit FE. UI Jakarta

Syamsudin (2016), Jurnal Sains Manajemen Vo. 2 No. 2 Juni 2016

Susanto. Change Management, Jakarta: Kompas, 7 Oktober 2001

Swastha dan Ibnu Sukotjo W. (2000), Pengantar Bisnis Modern, Cetakan Kedelapan, Yogyakarta, Liberty

Thoha, Miftah. (2001). Birokrasi Indonesia Dalam Era Globalisasi, Pusdiklat Pegawai Depdiknas, Sawangan, Bogor.

Wahyu Purnomo, Titin Isna Oesman, dan Muhammad Yusuf (2018). Jurnal Rekavasi Vol. 6 No. 1 Mei 2018, p. 47-52. ISSN 2338-7750 